those who pass them along. A good story should never be spoiled by that.

Pleasantrille, New York, JONATHAN WRIGHT January 18, 1921

\section{REPLY TO PROFESSOR HORN}

MaNY times has the undersigned been found to be in error on historical questions. It is not easy to write during a period of over thirty years without occasionally committing mistakes. Even Newton once said, "It's impossible to print the book without faults." However, it is due to myself to state that not all the errors attributed to me are errors in reality. In not a few cases the critics themselves are in error. But never, before the appearance of Professor D. W. Horn's letter (ScIENCE, January 14, 1921), have I been accused of "Romancing in Science." Had Professor Horn been less excited and more contemplative, he would have written differently. My account of Galileo was prepared a quarter of a century ago. Were I to re-write it, I would make some slight changes. "Prior to Galileo it did not occur to any one actually to try the experiment" relating to acceleration. More recent research reveals that Galileo, like most great scientific men, had his forerunners. I say that Galileo publicly experimented "one morning." This may have been the correct time of day, but I am not now able to verify the statement. Galileo "allowed a one pound shot and a one hundred pound shot to fall together." From Galileo's "Dialogues Concerning two New Sciences" it appears that he did perform this experiment, but I am not sure that these were the particular weights used when experimenting before the university assembly. I have gone over sentence by sentence the passage quoted by Professor Horn and the above are the only changes which seem to me perhaps necessary. I repel as unjust the charge that $I$ am "romancing in science."

Dr. Partridge rendered a service in calling attention ito Galileo's experiments at the Tower of Pisa. However, I still think that the Doctor overstated his case, was wrong in implying that Galileo made only one experiment, and without sufficient reason called in question the accuracy of Viviani's "Life of Galileo"-a life which Favaro, after very many years devoted to the study of Galileo, has found to be remarkably reliable. Of course, part of the discussion hinges on the word "exactly." No description of an experiment can be exact in every detail. However, if essentials suffice, then our knowledge of Galileo's experiments on falling bodies is exact, for we know exactly the purpose of the experiments, as well as the mode of experimentation, namely, the dropping of different weights of a variety of materials-mention being made of some of the materials dropped.

Professor Horn quotes: Fortis imaginatio generat causum. I agree, but whose casus is it really?

Florian Cajori

\section{UnIversity of CaLIfornia}

\section{A CORRECTION}

To THE Editor of Science: The times are actually worse than I realized when writing recently about "Romancing in Science." The opening quotation should have read " $\mathrm{O}$ tempora," instead of " $O$ tempus." The peculiar appropriateness of this quotation is apparent, for the correction came to me (from New York) as part of an anonymous letter!

\section{Bryn Mawr, Pennsyluania}

\section{David Wilbur HorN}

\section{MEMOIR OF G. K. GILBERT}

THE undersigned is engaged in the prepararation of a memoir of the late G. K. Gilbert, to be published by the National Academy of Sciences, and would be obliged if geclogists and others who possess letters from him or who recall incidents that throw light upon his character would submit them for ineorporation in the story of his life. His great contributions to geological science are published and fully accessible; but the smaller non-scientific matters which give the life of a man its finer savor can be learned only by personal communication from his friends. A good number of such communications have been already received; they are of so great 